Click www.researchjournal.co.in/online/subdetail.html to purchase.

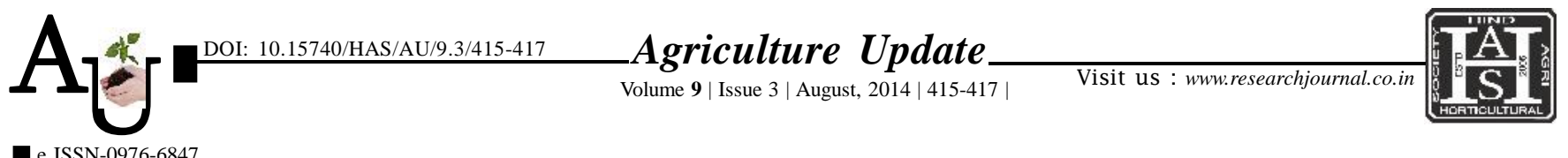

Research Article

\title{
Socio-economic characteristics of Bidi tobacco growers and factor associated with technological
} gap

\author{
SANTOSH SWAMI, NAGESH, G. N. MARADDI AND V. A. PAWAR
}

Article Chronicle: Summary : Study was conducted in Chikkodi and Hukkeri talukas of Belgaum district based on highest area Received : 27.09.2013;

Revised :

08.07.2014;

Accepted :

18.07.2014 under tobacco cultivation in the state. The expost-pacto research design was used for the study. Each of six villages were identified from two talukas, respectively, based on highest area under tobacco cultivation. Intern ten respondents were selected randomly from each village. Thus, the total sample size constituted 120 respondents. Data were personally collected by personal interview method using pre-structured interview schedule. Totally eight independent variables were studied in addition to dependent variables. The results revealed that majority of the respondents were middle aged. It was observed that out of the eight variables selected age and education showed non significant and negative relationship with technological gap. Economic status, size of holding and area under Bidi tobacco of respondents were found to have negative and significant relationship with technological gap.

How to cite this article : Swami, Santosh, Nagesh, Maraddi, G.N. and Pawar, V.A. (2014). Socio-economic characteristics of Bidi tobacco growers and factor associated with technological gap. Agric. Update, 9(3): 415-417.

KeY Words:

SES of tobacco

growers, Factors

of TG, Relationship

Author for correspondence :

\section{NAGESH}

Department of Agricultural

Extension Education,

College of Agriculture,

University of Agricultural

Sciences, RAICHUR

(KARNATAKA) INDIA

Email: samarth.nagesh

@ gmail.com

See end of the article for

authors' affiliations 